The educators-Yuri Guk, Saint Petersburg Law School; Olga Kravchenko of Bryansk; Nikolai Obdirshikov, Togliatti; Yuri Shipakin, Izhevsk, Udmurtia; and Tatyana Vereshagina, Kirov-spent 12 days visiting schools and organizations in Ohio, Kentucky, and Washington, DC, collecting information and sharing ideas on civic education. Their trip was sponsored by the Civitas International Exchange Program in partnership with APSA, the Grazhdanin Training Center, the American Federation of Teachers, and others. Escorting the Russians were Evgeny Belyakov, Moscow ofice director for Civitas and the AFT; Shannon McLeod, program coordinator, AFT Educational Foundation; and, as translator, Sasha Nikolskaya.

\section{Bradburn to Head NSF Directorate}

Norman M. Bradburn, vice president and former director of the National Opinion Research Center and Tiffany and Margaret Blake Distinguished Service Professor at the University of Chicago, has been chosen to succeed Bennett Bertenthal as assistant director of NSF's Directorate for Social, Behavioral and Economic Sciences. A pioneer in applying cognitive science methods to the design of survey questionnaires, Bradburn holds an M.A. in clinical psychology and a Ph.D. in social psychology, both from Harvard University. At NSF, he will oversee the activities of the Division of Social and Economic Sciences, Division of Behavioral and Cognitive Sciences, Division of Science Resource Studies, and Division of International Programs.

\section{Washington Insider}

\section{Census Undercount Costs Localities}

In a report commissioned by the Census Monitoring Board, analysts for PricewaterhouseCoopers gave evidence that an undercount of the U.S. population during the 2000 Census comparable to the undercount determined for the 1990 Census could cost some states as much as $\$ 5$ billion in federal funds between 2002 and 2012. The report, available on the board's web site (http:// cmbp.gov/v3/report/bystate/), gives estimated undercounts and projects the funding shortfalls for each state and 169 statistical metropolitan areas. Likely to be most affected are the largest states and cities, which also rely most heavily on federal sponsorship of programs like Medicaid, foster care, rehabilitation services, substance abuse prevention and treatment, and vocational education.

\section{OMB Drafts Guidance on Reporting, Using Race Data}

Individuals filling out government forms may now indicate more than one race and/or ethnicity. This change in policy, implemented in 1997, makes it possible for individuals to be categorized as members of 63 distinct single or multiple racial/ethnic groups. Which begs the question of how data on race and ethnicity will be tabulated, used to ensure compliance with

antidiscrimination laws, and compared across time. The federal Office of Management and Budget is currently developing official answers to these questions. The initial draft of guidelines for reporting and using newly collected race and ethnicity data was published in February 1999 and is available for review and comment on the OMB web site

(www.whitehouse.gov/omb/inforeg/index.htm|\#SP).

\section{House Historian's Office to Be Reinstated?}

A proposal to reestablish the position of Historian of the U.S. House of Representatives is being developed by the clerk of the House, Jeff Trandahl, despite opposition from the chair of committee that would have to approve any such plan. The historian's position has been vacant since 1995, when then-speaker Newt Gingrich (R-GA) ordered the office closed and its responsibilities transferred to the newly created legislative Resource Center. Bill Thomas (R-CA), who heads the House Administration Committee which oversees the LRC, has argued there is no need for a separate historian's office and promised not to consider reestablishment. There is some support for the idea among other members of Congress, however, and it is likely to be taken up next year.

\section{Important Washington People}

Sheila Burke, the current executive dean of the John F. Kennedy School of Government at Harvard, has accepted an appointment to become the Smithsonian Institution's under secretary for museums, programs, and national outreach. Among the museums she will supervise are Air and Space, American History, American Art, American Indian, and Postal. John W. Roberts has been named deputy chairman of the National Endowment for the Humanities. Roberts is a specialist in African-American folklore who has taught at the University of Pennsylvania and Ohio State University.

\section{Follow Ups}

- On March 6, 2000, the U.S. Supreme Court denied a petition from a group of plaintiffs led by Public Citizen that it review a 1999 federal appeals court ruling that allowed the National Archives and Records Administration to continue the policy of destroying electronic email records when paper copies of the same records were available. Archives administrators estimate they will have between 30 and 40 million email messages just from the White House to catalog and make accessible when Clinton leaves office.

- The staff of the U.S. Department of Energy's Office of Security and Emergency Operations is set to begin rereviewing more than $\mathbf{4 5 0}$ million pages of formerly classified federal documents to ensure that no nuclear weapon design information is inadvertently released. Most of the documents marked for rereview have been released pursuant to an executive order requiring the declassification of all but the most sensitive government records created more than 25 years ago. The rereview is mandated by a provision of the FY2000 Defense Appropriations Act.

Note: Information for this update was drawn from NCC Washington Update (http://www2 hnet.msu.edu/ ncc/ncc00/I, COSSA Washington Update (http://www.cossa.org/Update.htm), and NEH Outlook. 